\title{
ANALISIS PELUANG USAHA BAGI HASIL HUTAN TANAMAN JENIS Eucalyptus pellita F. Muell DAN Acacia mangium Willd DI KABUPATEN KUTAI KARTANEGARA PROVINSI KALIMANTAN TIMUR
}

\author{
Rusni Noor ${ }^{1}$, Abubakar M. Lahjie ${ }^{2 *}$, B.D.A.S. Simarangkir ${ }^{2}$ dan Yosep Ruslim ${ }^{2 * *}$ \\ ${ }^{1}$ Program Magister Ilmu Kehutanan, Fakultas Kehutanan \\ Universitas Mulawarman. \\ ${ }^{2}$ Fakultas Kehutanan Universitas Mulawarman. Jl. Ki Hajar Dewantara, Gunung Kelua, \\ Samarinda 75116, Kalimantan Timur, Indonesia.Tel.: +62-541-735089, Fax.: +62-541- \\ 735379. \\ E-Mail: rsn_smda@yahoo.co.id; prof_abudir@yahoo.com; \\ Email: yruslim@gmail.com
}

\begin{abstract}
ABSTRAK
Analisis Peluang Usaha Bagi Hasil Hutan Tanaman Jenis Eucalyptus pellita F. Muelldan dan Acacia mangium Willd di Kabupaten Kutai Kartanegara Provinsi Kalimantan Timur. Penelitian ini bertujuan untuk mengetahui riap pertumbuhan, tingkat pengembalian nominal dan kelayakan keuntungan profit sharing pengelolaan hutan tanaman Jenis Eucalyptus pellita F. Muell dan Acacia mangium Willd di Kabupaten Kutai Kartanegara Provinsi Kalimantan Timur. Analisis pertumbuhan riap dan produksi menggunakan metode riap MAI dan CAI pada perhitungan total volume, diameter dan tinggi pohon, serta untuk profit sharing menggunakan analisis kelayakan $i$ (tingkat pengembalian nominal). Hasil penelitian menunjukkan bahwa produksi/pertumbuhan Eucalyptus pellita F. Muell mencapai riap yang optimal pada umur 5 tahun dengan total volume sebesar $156,53 \mathrm{~m}^{3} /$ ha, riap MAI mencapai $31,31 \mathrm{~m}^{3} / \mathrm{ha} /$ thn dan CAI $31,35 \mathrm{~m}^{3} / \mathrm{ha} /$ thn sedangkan jenis Acacia mangium Willdmencapai riap yang optimal pada umur 5 tahun dengan total volume sebesar $150,22 \mathrm{~m}^{3} /$ ha, riap MAI mencapai $30,04 \mathrm{~m}^{3} / \mathrm{ha} / \mathrm{thn}$ dan CAI $30,50 \mathrm{~m}^{3} / \mathrm{ha} / \mathrm{thn}$. Analisis tingkat pengembalian nominal dan peluang usaha bagi hasil berbasis ekonomi konvensional Eucalyptus pellita F. Muelldengan sistem bagi hasil masing-masing mendapatkan 50\% baik untuk investor maupun pengelola menghasilkan tingkat pengembalian nominal sebesar $49,49 \%$. Analisis tingkat pengembalian nominal dan peluang usaha bagi hasil berbasis ekonomi konvensional jenis Acacia mangium Willddengan sistem bagi hasil masingmasing 50\% untuk investor dan pengelola menghasilkan tingkat pengembalian nominal sebesar 48,26\%.Tanaman jenis Eucalyptus pellita F. Muelldan Acacia mangium Willdsama-sama layak untuk diusahakan karena nilai tingkat pengembalian nominalnya lebih besar daripada tingkat bunga minimal yang diterima oleh investor (MAR).
\end{abstract}

Kata kunci : Eucalyptus pellita F. Muell,Acacia mangium Willd, peluang usaha, profit sharing.

\begin{abstract}
Analysis of Profit Sharing Business Opportunity for Wood Estates: Eucalyptus pellita F. Muell and Acacia mangium Willd, in Kutai Kartanegara Regency, East Kalimantan Province.This study aimed to determine growth increment, rate of nominal return, and profitability of profit sharing business in wood estates management of Eucalyptus pellita F. Muell and Acacia mangium Willd in Kutai Kartanegara Regency, East Kalimantan Province. Increment and production growths were analysed using increment methods: MAI and CAI by calculating total volume, diameter and tree height; Feasibility Analysis $i$ (nominal return rate) was applied for profit sharing analysis. The results showed that the production/growth of Eucalyptus pellita F. Muell reached optimal incremental growth at 5 years old with total volume of 156.53 $\mathrm{m}^{3} / \mathrm{ha}$; MAI value was $31.31 \mathrm{~m}^{3} / \mathrm{ha} / \mathrm{yr}$ and CAI value was $31.35 \mathrm{~m}^{3} / \mathrm{ha} / \mathrm{yr}$. While the production/growth of Acacia mangium Willd reached optimal incremental growth at same age with the former, total volume of the latter was lower at $150.22 \mathrm{~m}^{3} /$ ha with respectively MAI and CAI values were $30.04 \mathrm{~m}^{3} / \mathrm{ha} / \mathrm{yr}$ and 30.50 $\mathrm{m}^{3} / \mathrm{ha} / \mathrm{yr}$. Analysis of nominal return rate and profit sharing business opportunity based on conventional
\end{abstract}


economy for Eucalyptus pellita F. Muell with a profit sharing system showed that both investor and farmer respectively earned $50 \%$ - resulting a rate of nominal return at $49.49 \%$. Similarly, analysis of nominal return rate and profit sharing business opportunity based on conventional economy for Acacia mangium Willd with a profit sharing system showed that both investor and farmer respectively earned $50 \%$ - resulting a rate of nominal return at $48.26 \%$. Hence, both Eucalyptus pellita F. Muell and Acacia mangium Willd were equally feasible for profit sharing business since their values of the nominal return were greater than the minimum interest rate received by the investor (MAR).

Key words : Eucalyptus pellita F. Muell, Acacia mangium Willd, Business Opportunities, Profit Sharing.

\section{PENDAHULUAN}

Hutan merupakan sumberdaya alam yang sangat strategis dan memiliki karakteristik biologis serta ciri ekonomi khusus yang akan mempengaruhi terhadap kebijakan pengelolaan hutan. Sumbangan bidang kehutanan bagi perekonomian Indonesia secara sederhana dapat dilihat dari nilai ekspor Indonesia pada dasawarsa 1980-an dan 1990-an yang menduduki peringkat kedua di bawah ekspor migas. Dalam skala yang lebih kecil, akan lebih nyata dapat dibuktikan bahwa sumber daya hutan masih menjadi sandaran utama perekonomian sebagian besar masyarakat Indonesia, terutama masyarakat marginal. Oleh karenanya hutan seharusnya dikelola secara berkelanjutan agar dapat memberi manfaat sebesar-besarnya bagi rakyat Indonesia, sebagaimana amanat Undang-Undang Dasar 1945 (Maryunani \& Sutikno. 2006)

Kalimantan Timur merupakan salah satu provinsi di Indonesia yang memiliki hutan hujan tropis yang cukup luas dengan beberapa wilayah kabupaten dan kota yaitu Kabupaten Berau, Kabupaten Kutai Barat, Kabupaten Kutai Timur, Kabupaten Kutai Kartanegara, Kabupaten Paser, Kabupaten Penajam Paser Utara, Kabupaten Mahakam Ulu, Kota Bontang, Kota Samarinda, Kota Balikpapan. Dari 10 kabupaten dan kota tersebut, Kabupaten Kutai Kartanegara memiliki luas wilayah $27.263,10 \mathrm{~km}^{2}$ atau 2.726.310 Ha (12,89\% dari luas wilayah Provinsi Kalimantan Timur) berdasarkan peta Status Kawasan yang mengacu kepada Peta SK. Menhut No. 79/KptsII/2001 dan dari hasil analisis, 63,08\% wilayah daratan Kabupaten Kutai Kartanegara adalah berupa Kawasan Hutan (KBK, Kawasan Konservasi dan Hutan Lindung) dan 36,92\% berupa Areal Penggunaan Lain (APL) atau lebih kini dikenal dengan istilah Kawasan Budidaya Non Kehutanan (KBNK). Dari Areal KBK yang ada, sekitar 52,34\% merupakan kawasan hutan produksi yang dapat dimanfaatkan secara optimal untuk kesejahteraan rakyat dengan tetap melestarikan dan menjaga lingkungan hidup. Saat ini Terdapat 23 Perusahaan Industri Pengolahan Kayu (IPK) dengan luas areal $180.050,19$ ha dan produksinya 3.436.093,71 $\mathrm{m}^{3}$. (Bioma, 2013)

Sumberdaya hutan yang dimanfaatkan secara terus menerus guna meningkatkan kesejahteraan dan mutu hidup rakyat menyebabkan ketersediaannya menjadi terbatas dan tidak merata, baik dalam jumlah maupun dalam kualitas, sedang permintaan akan sumberdaya hutan semakin meningkat sebagai akibat meningkatnya kegiatan pembangunan untuk memenuhi kebutuhan penduduk yang kian beragam. Dampak tersebut mengakibatkan daya dukung hutan menjadi terganggu dan daya tampung hutan menjadi menurun. Tidak hanya sebatas nilai ekonomi untuk pemenuhan kebutuhan hidup masyarakat, dan sumber pendapatan/devisa Negara (economical loss) tetapi juga hutan kehilangan kekayaan keanekaragaman hayati (flora dan fauna) dan kerusakan alam (ecological loss) (Nurjaya, 2008). 
Menurut Forest Watch Indonesia,penurunan luas dan kondisi kawasan hutan di Kalimantan Timur berakibat pada menurunnya produktivitas hutan alam baik dari segi kwantitas (deforestasi) maupun kwalitasnya (forest degradation) dimana penyebab dari menurunnya produktivitas hutan tersebut adalah adanya operasional penebangan yang kurang terkendali untuk peningkatan pendapatan devisa Negara, maraknya penebangan liar (ilegall logging), perambahan dan konversi lahan hutan menjadi areal lain seperti lahan pertambangan, perkebunan dan pemukiman serta kebakaran yang terjadi secara alami akibat dari kekeringan yang panjang maupun non alami.

Penurunan produktivitas hutan alam yang telah mengakibatkan berkurangnya suplai hasil hutan kayu yang dapat dimanfaatkan dalam bidang industri kehutanan. Hal ini mendorong adanya upaya pembangunan Hutan Tanaman sebagai solusi untuk memenuhi suplai bahan baku kayu baik melalui Izin Usaha Pemanfaatan Hasil Hutan Kayu pada Hutan Tanaman Rakyat (IUPHHKHTR) maupun Izin Usaha Pemanfaatan Hasil Hutan Kayu pada Hutan Tanaman Industri (Kusumaningrum, 2015)

Berbagai kebijakan-kebijakan ekonomi dan finansial harus seimbang dengan system perekonomian yang digunakan. Selama ini sistem ekonomi konvensional yang banyak dikenal dengan sistem klasik ini mempunyai kaitannya dengan "kebebasan alami" (proses) yang di pahami oleh tokoh-tokoh ekonomi sebagai ekonomi liberal klasik yang cenderung hanya menguntungkan salah satu pihak saja dalam hal ini sipemilik modal saja. Konsep profit sharing atau disebut juga dengan profit and loss sharing adalah pembagian hasil usaha dengan perhitungan pendapatan/keuntungan bersih (net benefit), laba kotor dikurangi beban biaya yang dikeluarkan selama operasional usaha (Rivai dan Arifin, 2010). Atas dasar itulah yang melatarbelakangi penelitian terhadap peluang usaha bagi hasil (profit sharing) pengusahaan hutan tanaman jenis Eucalyptus pellita F. Muell dan Acacia mangium Willd di Kabupaten Kutai Kartanegara Provinsi Kalimantan Timurdengan berbasis pengelolaan secara konvensional yang mampu memberikan keuntungan bagi investor dan pengelola.

\section{METODA PENELITIAN}

\subsection{Tempat dan Waktu}

Lokasi penelitian dilaksanakan di PT Surya Hutani Jaya yang wilayah kerjanya masuk kedalam Kabupaten Kutai Kartanegara dan kabupaten Kutai Timur, Provinsi Kalimantan Timur. Pelaksanaan kegiatan penelitian dilaksanakan bulan November 2018 sampai dengan bulan Maret 2019. (Gambar 1). 


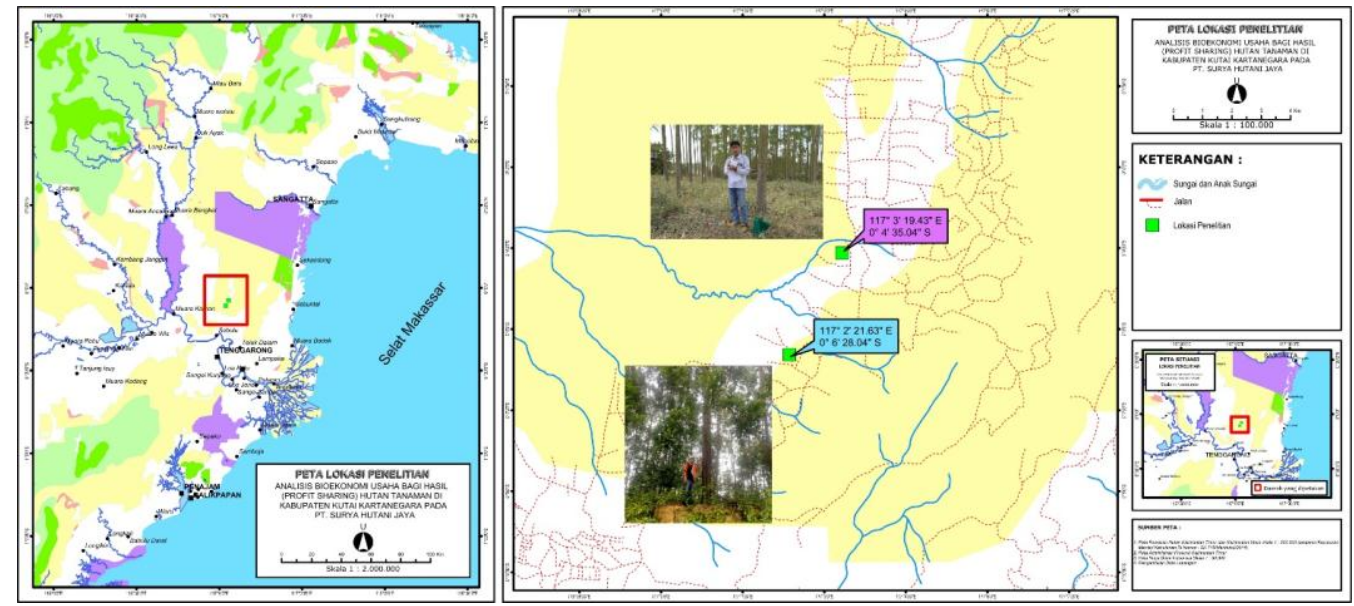

Gambar 1. Peta lokasi pengambilan data penelitian

2.2. Objek dan Data Penelitian

Objek penelitian berupa tegakan jenis hutan tanaman yaitu Eucalyptus pellita F. Muell dan Acacia mangium Willd. Jarak tanam kedua jenis hutan tanaman tersebut adalah $3 \mathrm{~m} \times 2,5 \mathrm{~m}$ yang diukur pada petak tanaman umur 1, 2, 3, 4, 5 dan 6 tahun dengan metode pengambilan data secara sistematik atau systematic random sampling.

Menurut Arikunto (2010), bahwa bila objek penelitian jumlahnya kurang dari 100 lebih baik diambil semua, jika jumlahnya besar atau lebih dari 100 dapat diambil antara $10-15 \%$ atau 20-25\% atau lebih, tergantung waktu, tenaga dan luas wilayah pengamatan, atau besar sedikitnya data dan besarnya risiko penelitian serta tingkat homogenitas sampel. Maka kami mengambil sampel penelitian sebesar 20\%. Adapun jumlah sampel pada masing-masing plot dapat dilihat pada Tabel 1.

Tabel 1. Jumlah sampel pada masing-masing petak tanaman

\begin{tabular}{llcccc}
\hline No. & \multicolumn{1}{c}{ Jenis tegakan } & Jarak Tanam & Luas $\left(\mathbf{m}^{2}\right)$ & N/ha & Sampel 20\% \\
\hline 1. & Eucalyptus pellita F. Muell & $3 \mathrm{~m} \times 2,5 \mathrm{~m}$ & 10.000 & 1.333 & 267 \\
2. & Acacia mangium Willd & $3 \mathrm{~m} \times 2,5 \mathrm{~m}$ & 10.000 & 1.333 & 267 \\
\hline
\end{tabular}

\subsection{Analisis Data}

2.3.1. Menghitung volume suatu tegakan dengan menggunakan persamaan Berkhout (Loetsch, Zohrer dan Haller, 1973). Suhendang (1997) dalam Wood dan Wiant (1993), menyatakan bahwa menurut Bruce Schumacher (1950), penurunan model Berkhout untuk perhitungan volume suatu tegakan menggunakan rumus: $\mathrm{V}=\boldsymbol{\pi} \quad \mathbf{x} \quad \mathbf{x} \quad \mathbf{f}$ sedangkanuntuk menghitung riap menggunakan rumus MAI dan CAI. (Prodan, M, 1968)

2.3.2. Menghitung bagi hasil dan kelayakan dengan menggunakan rumus tingkat bunga pengembalian nominal (Nominal rate of return/NRR) (Muluk, 2014)yaitu :

$$
i=\sqrt[n]{\frac{v n}{v o}}-1
$$


2.3.3. Menghitung tingkat bunga pengembalian minimial(Klemperer, 2003) yang dapat diterima (Minimum acceptable rate of return/MAR) oleh investor, sebagai pembanding hasil dari tingkat bunga pengembalian tingkat bunga nominal. Apabila MAR \& NRR, maka usaha tersebut disebut layak.

MARR $=\frac{1+i}{1+f}-1$

dimana :

$\mathrm{i}=$ tingkat bunga deposito (saat ini $10 \%)$

$\mathrm{f}=$ inflasi (saat ini 7\%)

\section{HASIL PENELITIAN DAN PEMBAHASAN}

3.1. Riap Pertumbuhan Tanaman jenis Eucalyptus pellita F. Muell

Riap dibedakan ke dalam riap tahunan berjalan (Current Annual Increament/CAI) dan riap rata-rata tahunan (Mean Annual Increament/MAI). CAI adalah riap dalam satu tahun berjalan atau riap dalam satu waktu periode tertentu, sedangkan MAI adalah riap rata-rata per tahun yang terjadi sampai periode waktu tertentu (Prodan, M., 1968).

Eucalyptus pellita F. Muelldi PT Surya Hutani Jaya dengan jarak tanam $3 \mathrm{~m} \times 2,5 \mathrm{~m}$ pada awal penanaman memiliki jumlah pohon sebanyak 1.333 Ha. Setelah berumur 1 tahun mengalami pengurangan jumlah pohon sebanyak 93 pohon sehingga jumlah pohon menjadi 1.240 pohon akibat adanya kematian alami dengan rata-rata diameter sebesar $5,2 \mathrm{~cm}$ dan rata-rata tinggi sebesar 4,4 m. Pada umur tanaman 3 tahun jumlah pohon berkurang menjadi 1.060 pohon dengan rata-rata diameter sebesar 10,1 $\mathrm{cm}$ dan rata-rata tinggi sebesar $12,9 \mathrm{~m}$ dengan total volume sebesar 76,27 $\mathrm{m}^{3} /$ hadan riap MAI dan CAI berturutturut sebesar 25,42 dan $36,92 \mathrm{~m}^{3} / \mathrm{ha} / \mathrm{thn}$.

Pada umur 5 tahun, jumlah pohon menjadi 897 pohon dengan rata-rata diameter sebesar $14,7 \mathrm{~cm}$ dan rata-rata tinggi sebesar $15,5 \mathrm{~m}$. Sedangkan total volume pada usia tanaman 5 tahun adalah sebesar $156,53 \mathrm{~m}^{3} /$ hadan diperoleh riap MAI mencapai $31,31 \mathrm{~m}^{3} / \mathrm{ha} /$ thn dan CAI mencapai $31,35 \mathrm{~m}^{3} / \mathrm{ha} / \mathrm{thn}$. Adapun data tersebut dapat dilihat pada tabel berikut.

Tabel 2. Pertumbuhan dan riap volume Eucalyptus pellita F. Muell

\begin{tabular}{cccccccc}
\hline $\mathbf{y}$ & $\mathbf{n}$ & $\mathbf{d}$ & $\mathbf{h}$ & $\mathbf{f}$ & $\mathbf{T V}$ & MAI & CAI \\
\hline 1 & 1.240 & 5,2 & 4,4 & 0,75 & 8,67 & 8,67 & \\
2 & 1.116 & 8,1 & 9,3 & 0,73 & 39,35 & 19,68 & 30,68 \\
3 & 1.060 & 10,1 & 12,9 & 0,70 & 76,27 & 25,42 & 36,92 \\
4 & 979 & 12,9 & 14,2 & 0,69 & 125,18 & 31,30 & 48,91 \\
5 & 897 & 14,7 & 15,5 & 0,66 & 156,53 & 31,31 & 31,35 \\
6 & 825 & 15,8 & 17,1 & 0,65 & 180,21 & 30,04 & 23,68 \\
\hline
\end{tabular}

Keterangan :

y $\quad=$ umur tanaman

$\mathrm{n} \quad=\operatorname{populasi}(\mathrm{phn} / \mathrm{ha})$ 


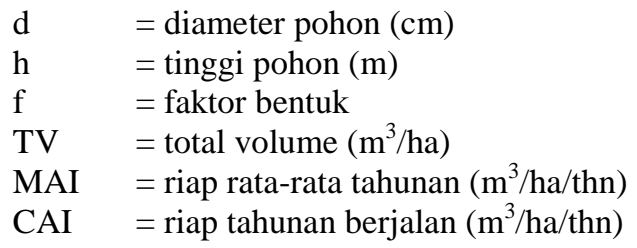

Tabel 2 menjelaskan bahwa pertumbuhan tanaman Eucalyptus pellita F. Muellmempunyai riap optimal pada umur 5 tahun, dengan total volume $156,53 \mathrm{~m}^{3} /$ ha, sehingga diperoleh MAI mencapai $31,31 \mathrm{~m}^{3} / \mathrm{ha} / \mathrm{thn}$ dan CAI mencapai $31,35 \quad \mathrm{~m}^{3} / \mathrm{ha} / \mathrm{thn}$ dan berkurangnya jumlah pohon setiap tahun disebabkan oleh kematian alami dan penjarangan.

Hubungan antara MAI dan CAI Eucalyptus pellita F. Muelldi PT Surya Hutani Jaya berdasarkan Tabel 2 dapat dilihat pada Gambar 2.

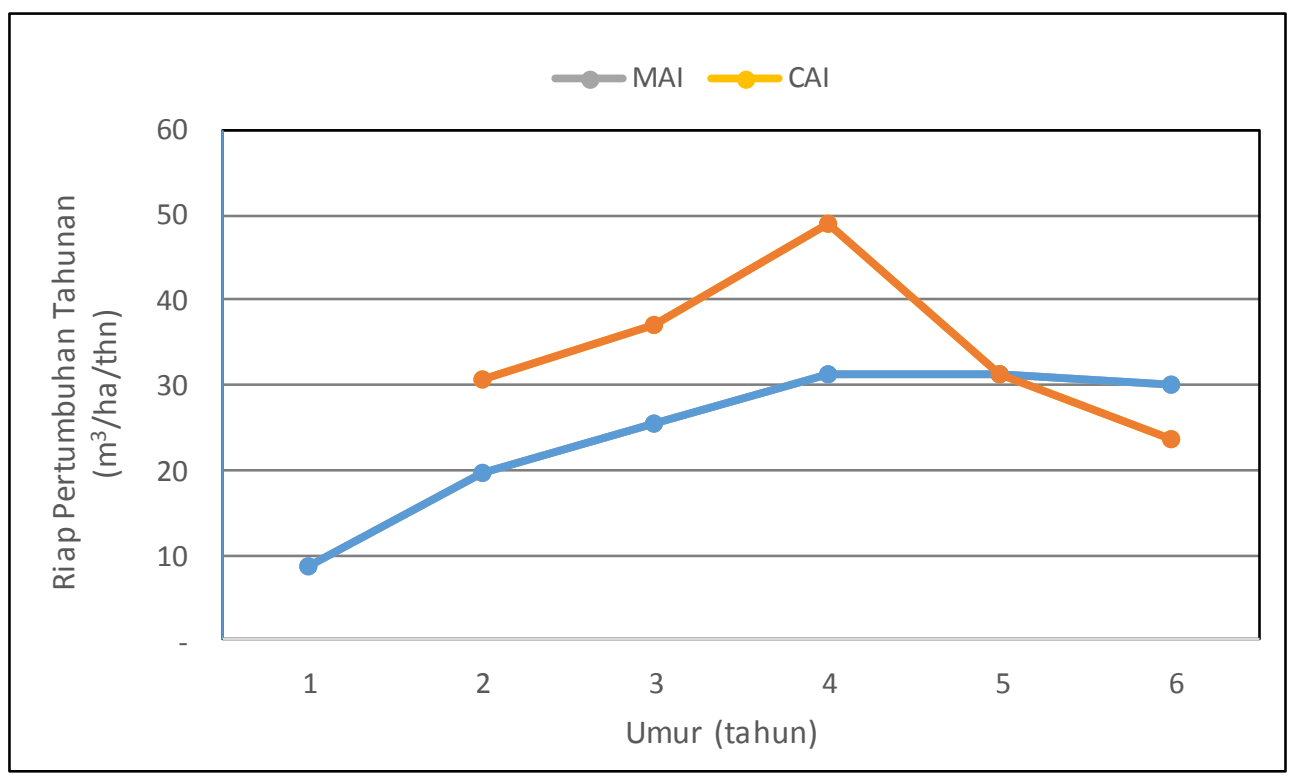

Gambar 2. Kurva hubungan MAI dan CAI pada tegakan Eucalyptus pellita F. Muell

Pada gambar 2 terlihat bahwa berdasarkan data pengukuran perpotongan kurva MAI dan CAI pada umur 5 tahun dimana MAI maksimum adalah 31,31 $\mathrm{m}^{3} / \mathrm{ha} / \mathrm{thn}$ dan CAI maksimum adalah $31,35 \mathrm{~m}^{3} / \mathrm{ha} / \mathrm{thn}$. Hal ini menunjukkan bahwa tegakan Eucalyptus pellita F. Muell di PT Surya Hutani Jaya yang sebagian besar kawasannya berada di Kabupaten Kutai Kartanegara provinsi Kalimantan Timur dalam rentang waktu 5 tahun sudah dapat dilakukan pemanenan karena telah mencapai riap maksimum serta sudah bisa mencapai keuntungan finansial sebagai bahan baku industri pulp dan kertas.

Penurunan daur pemanenan Eucalyptus pellita F. Muell di PT Surya Hutani Jaya tidak berpengaruh terhadap kuantitas dan kualitas kayu yang dihasilkan terutama pada kriteria serat kayu yang dihasilkan, akan tetapi populasi tegakan Eucalyptus pellita F. Muell yang tumbuh dari sejak ditanam hingga masa panen hanya mencapai ratarata $65 \%$ per hektarnya, hal ini disebabkan karena selain setiap tahunnya beberapa tanaman secara alami 
mengalami kematian baik akibat dari peningkatan riap diameter maupun adanya hama dan penyakit tetapi juga menurunnya tingkat kesuburan tanah akibat kurangnya pemupukan, hal ini akan terlihat pada saat daur tanam dan panen berikutnya di lahan yang sama. Sehingga upaya yang harus dilakukan adalah dengan pemupukan dan penambahan unsur hara secara intensif untuk meningkatkan kesuburan tanah.

\subsection{Riap Pertumbuhan Tanaman jenis} Acacia mangium Willd

Acacia mangium Willd di PT Surya Hutani Jaya dengan jarak tanam $3 \mathrm{~m} x$ $2,5 \mathrm{~m}$ pada awal penanaman memiliki jumlah pohon sebanyak 1.333 Ha. Setelah berumur 1 tahun mengalami pengurangan jumlah pohon sebanyak 200 pohon sehingga jumlah pohon menjadi 1.133 pohon akibat adanya kematian alami dengan rata-rata diameter sebesar $5,3 \mathrm{~cm}$ dan rata-rata tinggi sebesar 4,3 $\mathrm{m}$. Pada umur tanaman 3 tahun jumlah pohon berkurang menjadi 868 pohon dengan rata-rata diameter sebesar 11,6 $\mathrm{cm}$ dan rata-rata tinggi sebesar 11,6 m dengan total volume sebesar 77,41 $\mathrm{m}^{3} /$ hadan riap MAI dan CAI berturutturut sebesar 25,80 dan 43,52 $\mathrm{m}^{3} / \mathrm{ha} / \mathrm{thn}$.

Pada umur 5 tahun, jumlah pohon yang tumbuh menjadi 706 pohon dengan rata-rata diameter sebesar $16,5 \mathrm{~cm}$ dan rata-rata tinggi sebesar $15,1 \mathrm{~m}$. Sedangkan total volume pada usia tanaman 5 tahun adalah sebesar 150,22 $\mathrm{m}^{3} /$ hadan diperoleh riap MAI mencapai $30,04 \mathrm{~m}^{3} /$ ha/thn dan CAI mencapai 30,50 $\mathrm{m}^{3} / \mathrm{ha} / \mathrm{thn}$. Adapun data tersebut dapat dilihat pada tabel berikut.

Tabel 3. Pertumbuhan dan riap volume Acacia mangium Willd

\begin{tabular}{cccccccc}
\hline $\mathbf{y}$ & $\mathbf{n}$ & $\mathbf{d}$ & $\mathbf{h}$ & $\mathbf{f}$ & $\mathbf{T V}$ & MAI & CAI \\
\hline 1 & 1.133 & 5,3 & 4,3 & 0,76 & 8,12 & 8,12 & \\
2 & 986 & 8,5 & 8,2 & 0,74 & 33,89 & 16,95 & 25,77 \\
3 & 868 & 11,6 & 11,6 & 0,73 & 77,41 & 25,80 & 43,52 \\
4 & 772 & 14,4 & 13,8 & 0,69 & 119,72 & 29,93 & 42,31 \\
5 & 706 & 16,5 & 15,1 & 0,66 & 150,22 & 30,04 & 30,50 \\
6 & 635 & 18,1 & 16,6 & 0,64 & 173,58 & 28,93 & 23,36 \\
\hline
\end{tabular}

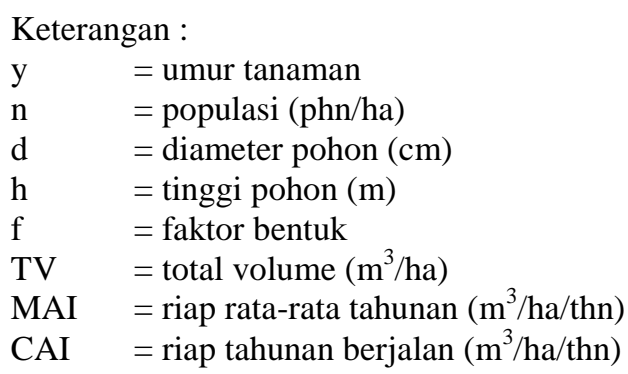

Tabel 3 menjelaskan bahwa pertumbuhan tanaman Acacia mangium Willdmempunyai riap optimal pada umur 5 tahun, dengan total volume 150,22 $\mathrm{m}^{3} /$ ha, sehingga diperoleh MAI mencapai $30,04 \mathrm{~m}^{3} /$ ha/thn dan CAI mencapai 30,50 $\mathrm{m}^{3} / \mathrm{ha} /$ thn dan berkurangnya jumlah 
pohon setiap tahun disebabkan oleh kematian alami dan penjarangan.

Hubungan antara MAI dan CAI jenis Acacia mangium Willddi PT Surya
Hutani Jaya berdasarkan Tabel 3 dapat dilihat pada Gambar 3.

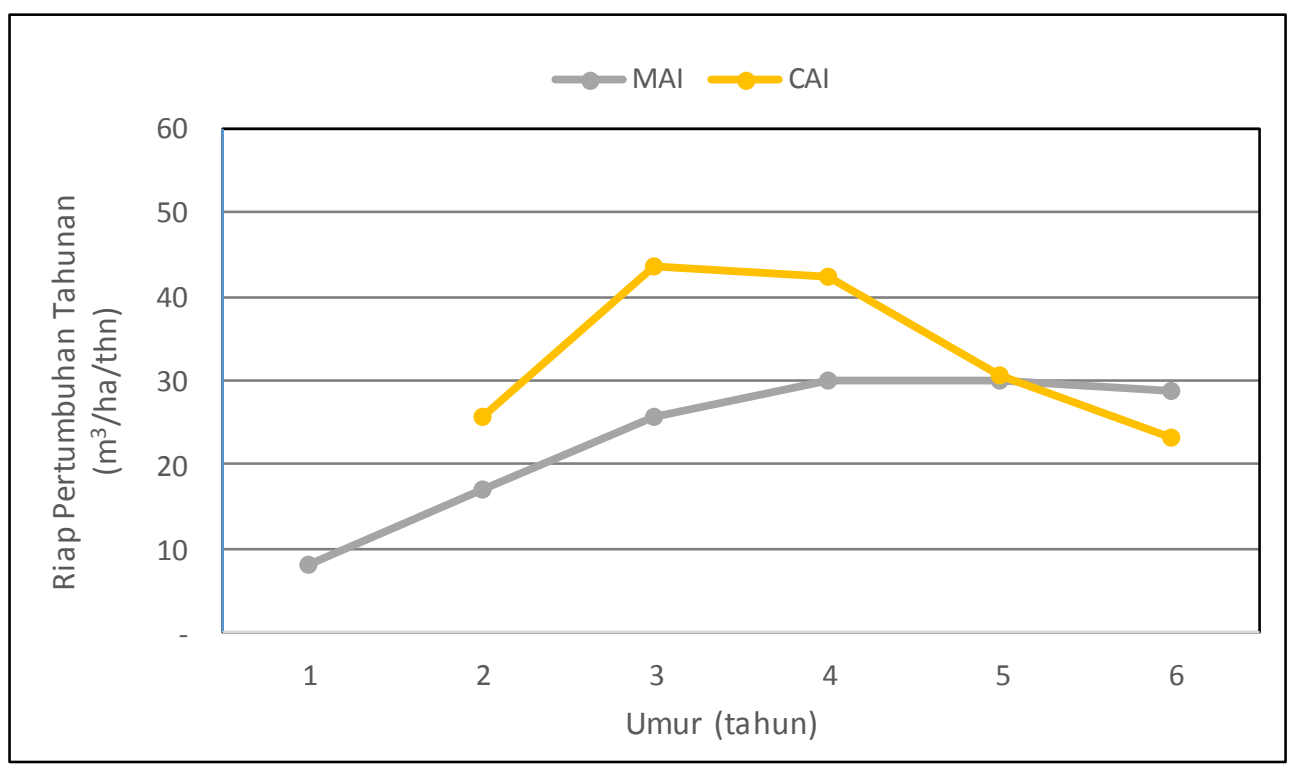

Gambar 3. Kurva hubungan MAI dan CAI pada tegakan Acacia mangium Willd

Pada gambar 3 terlihat perpotongan kurva MAI dan CAI pada jenis Acacia mangium Willdterjadi pada umur 5 tahun dengan riap optimal MAI sebesar 30,04 $\mathrm{m} 3 / \mathrm{ha} / \mathrm{thn}$ dan CAI sebesar 30,50 $\mathrm{m} 3 / \mathrm{ha} /$ thn serta riap mengalami penurunan pada tahun-tahun berikutnya. Hal ini berarti bahwa jika ingin melakukan kegiatan produksi maka pada umur 5 tahun Acacia mangium Willdlayak untuk ditebang meskinpun pada tahun berikutnya memiliki total volume yang lebih besar, namun riapnya mengalami penurunan.

Menurut Avery (1952), titik potong antara CAI dan MAI merupakan saat pemanenan yang paling efisien untuk mendapatkan produksi maksimum. Hal ini disebabkan karena setelah titik potong tersebut kedua kurva akan menurun yang berarti riap akan terus menurun.

\subsection{Analisis Tingkat Pengembalian} Nominal dan Peluang Usaha Bagi Hasil Berbasis Ekonomi
Konvensional jenis Eucalyptus pellita F. Muell dan Acacia mangium Willd di Kabupaten Kutai Kartanegara Provinsi Kalimantan Timur.

Sebelum melakukan kegiatan pengusahaan tanaman jenis Eucalyptus pellita F. Muell dan Acacia mangium Willd di Kabupaten Kutai Kartanegara Provinsi Kalimantan Timur dengan sistem konvensional terdapat beberapa asumsi yang harus diperhatikan dan digunakan dalam pengelolaan profit sharing/bagi hasilnya yaitu :

a. Para pengelola telah menanam terlebih dahulu jenis hutan tanaman, paling tidak tanaman telah berumur 5 tahun.

b. Antara investor dan pengelola harus ada kerjasama atau perjanjian (MoU) dengan suatu pabrik, dan mengenai harga kayu harus ada kontinyuitas atau sudah ditetapkan sebelumnya, untuk menghindari harga fluktuatif yang disebabkan oleh makelar kayu. 
c. Adanya dukungan dari pihak perbankan untuk menunjang permodalan awal usaha apabila pengusahaannya dikelola oleh masyarakat atau koperasi.

d. Tersedianya lahan bagi pengelola modal untuk kegiatan pengusahaan hutan tanaman yang tidak terkendala dengan perizinan termasuk lokasi yang dimiliki dalam keadaan normal dengan curah hujan yang cukup dan tidak memiliki resiko tinggi terhadap bencana alam seperti gempa ataupun kebakaran.

e. Tersedianya pembenihan dan bibit yang cukup dalam jumlah yang dibutuhkan.

f. Perlu adanya sosialisasi kepada masyarakat sekitar kawasan terkait peluang usaha bagi hasil pengusahaan hutan tanaman.

g. Berdasarkan Peraturan Pemerintah No.6 Tahun 2007, dimana pemerintah memberikan lahan seluas 15 hektare bagi setiap Kepala Keluarga (KK). Dengan asumsi 100 Kepala Keluarga (KK) maka luas lahan yaitu 1500 ha untuk memenuhi kapasitas pabrik.

Eucalyptus pellita F. Muell dan Acacia mangium Willdmerupakan jenis tanaman fast growing species yang dapat berproduksi optimal pada umur 5 tahun, namun untuk populasi tegakan akan berkurang setiap tahunnya akibat kematian tanaman secara alami sehingga dapat meningkatkan riap diameternya.

Tingkat pengembalian nominal $(i)$ merupakan tingkat pengembalian yang di dapatkan dari investasi dan di ukur dalam dollar yang sedang berlaku (termasuk inflasi) (Muluk, 2014). Untuk menentukan nilai net benefit yang didapatkan investor, terlebih dahulu menghitung nilai $(i)$ atau pengembalian nominal yang akan diperoleh, nilai (i) digunakan untuk menentukan diskon faktor yang akan didapatkan oleh investor dan pengelola sesuai dengan sistem yang telah disetujui. Untuk mendapatkan nilai (i) harus mengetahui pendapatan total (Vn), modal (Vo) dan daur (n). Modal awal dari biaya penanaman adalah $\mathrm{Rp}$ 13.000.000,-/ha dimana dari investor sebesar Rp 6.500.000 dan dari pengelola Rp 6.500.000,- dan untuk harga kayu yaitu sebesar $\mathrm{Rp} 620.000,-/ \mathrm{m}^{3}$ dengan daur panen 5 tahun. Sedangkan untuk memperoleh pendapatan total pada daur optimal, kita harus mengetahui Total Volume (TV).

Perhitungan untuk jenis Eucalyptus pellita F. Muell melalui perhitungan berikut.

$$
\begin{aligned}
\mathrm{TV} & =\mathrm{V} x \mathrm{n} \\
& =\frac{1}{4} \pi\left(\frac{d^{\mathrm{a}}}{10000}\right) * h * f * n \\
& =\frac{1}{4} * 3,14\left(\frac{14 \mathrm{~J}^{2}}{10000}\right) * 15,5 * 0,66 * 897 \\
& =156,53 \mathrm{~m}^{3} / \mathrm{ha} \\
\mathrm{Vn} & =\mathrm{TV} x \mathrm{harga} \\
& =156,53 \mathrm{~m}^{3} / \mathrm{ha} * \mathrm{Rp} 620.000,-/ \mathrm{m}^{3} \\
& =\mathrm{Rp} 97.048 .600,-/ \mathrm{ha}
\end{aligned}
$$

Hasil Vn tersebut dibagi sesuai dengan sistem yang telah disetujui yaitu untuk investor dan pengelola masingmasing sebesar 50\% sehingga diperoleh $\mathrm{Vn}$ untuk investor dan pengelola masingmasing sebesar $\mathrm{Rp}$ 48.524.300,-. Maka tingkat pengembalian nominal jenis Eucalyptus pellita F. Muell baik bagi investor maupun pengelola adalah sebagai berikut:

$$
\begin{aligned}
i & =\sqrt[n]{\frac{W_{n}}{W_{0}}-1} \\
& =\sqrt[ \pm]{\frac{48.524 .300}{6.500 .000}-1}=49,49 \%
\end{aligned}
$$

Berdasarkan perhitungan tingkat pengembalian nominal Eucalyptus pellita F. Muell yang riap optimalnya dicapai pada umur 5 tahun ternyata dapat simpulkan bahwa peluang kerjasama bagi hasil secara konvensional antara investor 
dan pengelola akan menghasilkan tingkat pengembalian nominal sebesar 49,49\%. Dari data tersebut, maka pengusahaan tanaman jenis Eucalyptus pellita F. Muell yang memiliki riap optimal pada umur 5 tahun layak untuk di usahakan karena nilainya lebih besar dari MAR, dimana saat ini MAR adalah 2,8\%.

Demikian juga dengan pertumbuhan jenis Acacia mangium Willd yang mencapai riap optimal pada umur 5 tahun dengan riap MAI sebesar $30,04 \mathrm{~m}^{3} / \mathrm{ha} / \mathrm{thn}$ dan riap CAI sebesar $30,50 \mathrm{~m}^{3} / \mathrm{ha} / \mathrm{thn}$, serta total volume sebesar $150,22 \mathrm{~m}^{3} / \mathrm{ha}$. Jika harga kayu sebesar Rp $620.000,-/ \mathrm{m}^{3}$, maka total pendapatan dari jenis Acacia mangium Willdsebesar Rp 93.136.400,dan biaya investasi sebesar $\mathrm{Rp}$ 13.000.000,- dimana pihak investor dan pihak pengelola masing-masing sebesar Rp 6.500.000,-.

Perhitungan untuk memperoleh pendapatan total pada daur optimal jenis Acacia mangium Willd adalah sebagai berikut:

$$
\begin{aligned}
\mathrm{TV} & =\mathrm{V} x \mathrm{n} \\
& =\frac{1}{4} \pi\left(\frac{\mathrm{d}^{\mathrm{a}}}{10000}\right) * h * f * \mathrm{n} \\
& =\frac{1}{4} * 3,14\left(\frac{16, \mathrm{~s}^{2}}{10000}\right) * 15,1 * 0,66 * 706 \\
& =150,22 \mathrm{~m}^{3} / \mathrm{ha} \\
\mathrm{Vn} & =\mathrm{TV} x \mathrm{harga} \\
& =150,22 \mathrm{~m}^{3} / \mathrm{ha} * \mathrm{Rp} 620.000,-/ \mathrm{m}^{3} \\
& =\mathrm{Rp} 93.136 .400,-/ \mathrm{ha}
\end{aligned}
$$

Hasil Vn (total pendapatan) jenis Acacia mangium Willd pada umur 5 tahun sebesar Rp 93.136.400,-/ha tersebut dibagi sesuai dengan sistem bagi hasil secara konvensional yang telah disepakati dengan pembagian sama masing-masing pihak investor dan pihak pengelola sebesar 50\% sehingga diperoleh masingmasing sebesar Rp46.568.200,-/ha. Maka tingkat pengembalian nominal jenis Acacia mangium Willd baik bagi investor maupun pengelola dapat dilihat dalam perhitungan di bawah ini:

$$
\begin{aligned}
i & =\sqrt[n]{\frac{W_{n}}{W_{0}}-1} \\
& =\sqrt[5]{\frac{46.568 .200}{6.500 .000}-1}=48,26 \%
\end{aligned}
$$

Berdasarkan perhitungan tingkat pengembalian nominal jenis Acacia mangium Willdyang riap optimalnya dicapai pada umur 5 tahun ternyata dapat simpulkan bahwa peluang kerjasama bagi hasil secara konvensional antara investor dan pengelola akan menghasilkan tingkat pengembalian nominal sebesar $48,26 \%$. Dari data tersebut, maka pengusahaan tanaman jenis Acacia mangium Willd yang memiliki riap optimal pada umur 5 tahun layak untuk di usahakan karena nilainya lebih besar dari MAR, dimana saat ini MAR adalah 2,8\%.

Jadi dapat disimpulkan bahwa pengusahaan hutan tanaman jenis Eucalyptus pellita F. Muell dan jenis Acacia mangium Willddengan sistem bagi hasil secara konvesional sama-sama layak untuk diusahakan.

Penelitian yang serupa tentang analisis peluang usaha bagi hasil yang dilakukan oleh Soares, M (2018) yang menyatakan bahwa Pengusahaan hutan tanaman jenis Shorea leprosula dan Shorea smithiana di PT Inhutani I Bukit Bangkirai Balikpapan sangat layak untuk diusahakan karena memiliki kriteria NPV $>0$ (nol). Tingkat bunga pengembalian nominal bagi Investor dan Pengelola dalam sistem ekonomi konvensional untuk jenis Shorea leprosulaadalah sebesar $7,8 \%$ dan $8,3 \%$, sedangkan untuk jenis Shorea smithiana berturut-turut sebesar 6,3\% dan 6,7\%. Begitu juga penelitian yang dilakukan oleh Anggoro (2016) dimana pengusahaan hutan tanaman jenis jabon merah di PT Intraca Wood menggunakan profit sharing sangat layak untuk digunakan karena memiliki kriteria NPV $>0$ (nol). Tingkat bunga 
pengembalian nominal bagi investor dan pengelola dalam sistem ekonomi konvensional masing-masing sebesar $28 \%$ dan 33\%. Sedangkan penelitian yang di lakukan oleh Rosalina (2016) juga menyatakan bahwa Profit sharing sengon berbasis konvensional menunjukkan tingkat pengembalian nominal untuk plot 1 sebesar $30 \%$ dan plot 2 sebesar 33\%. Pada pengusahaan hutan tanaman sengon sangat layak untuk diusahakan karena nilai indikator kelayakan net present value dengan nilai lebih dari nol (0). Dari ketiga penelitian terdahulu dan penelitian yang telah dilakukan saat ini maka dapat disimpulkan bahwa pengusahaan hutan tanaman dengan menggunakan analisis profit sharing/bagi hasil secara konvensional semuanya layak untuk diusahakan.

\section{KESIMPULAN}

Riap pertumbuhan optimal jenis Eucalyptus pellita F. Muelldicapai pada umur 5 tahun dengan total volume sebesar 156,53 $\mathrm{m}^{3} / \mathrm{ha}$, riap MAI mencapai $31,31 \mathrm{~m}^{3} / \mathrm{ha} / \mathrm{thn}$ dan CAI mencapai $31,35 \mathrm{~m}^{3} / \mathrm{ha} / \mathrm{thn}$ sedangkan jenis Acacia mangium Willd riap optimal dicapai pada umur 5 tahun dengan total volume sebesar $150,22 \mathrm{~m}^{3} / \mathrm{ha}$, riap MAI mencapai $30,04 \mathrm{~m}^{3} / \mathrm{ha} / \mathrm{thn}$ dan riap CAI mencapai $30,50 \mathrm{~m}^{3} / \mathrm{ha} / \mathrm{thn}$. Besarnya riap rata-rata tahunan maksimal tergantung dari kerapatan/jumlah pohon per hektar, jenis tanaman dan tingkat kesuburan tanah.

Analisis tingkat pengembalian nominal dan peluang usaha bagi hasil berbasis ekonomi konvensional jenis Eucalyptus pellita F. Muell pada umur 5 tahun didapatkan bagi investor dan pengelola menghasilkan tingkat pengembalian nominal sebesar 49,49\%. Sedangkan jenis Acacia mangium
Willdyang riap optimalnya juga dicapai pada umur 5 tahun menghasilkan tingkat pengembalian nominal sebesar 48,26\% baik bagi investor maupun pengelola, sehingga kedua jenis tanaman ini samasama layak untuk diusahakan karena nilai tingkat pengembalian nominalnya lebih besar daripada Minimum Acceptable Rate of return (MAR).

\section{UCAPAN TERIMA KASIH}

Disampaikan ucapan terima kasih kepada Pimpinan dan Pihak Manajemen PT Surya Hutani Jaya Site Sebulu Kabupaten Kutai Kartanegara Provinsi Kalimantan Timur termasuk Petugas Lapangan bagian Plantation Forest yang telah memberikan bantuan kesempatan untuk melakukan penelitian di wilayah kerja IUPHHK-HT PT Surya Hutani Jaya.

\section{DAFTAR PUSTAKA}

Anggoro, F. T. 2016. Analisis Profit Sharing Pengusahaan Hutan Tanaman Jabon Merah berbasis Konvensional di PT Intraca Hutani Lestari Kabupaten Tana Tidung Provinsi Kalimantan Utara. Skripsi. Fakultas Kehutanan Universitas Mulawarman, Samarinda.

Arikunto, S. 2010. Prosedur Penelitian Suatu Pendekatan Praktik. Jakarta: Rineka Cipta.(3): 134-185

Bioma, 2013, Album Peta Fasilitasi dan Advokasi Kesiapan Masyarakat dan Pemerintah Lokal Dalam Kerangka Potensi Proyek REDD+ di Mahakam Tengah Kabupaten Kutai Kartanegara, Kalimantan Timur. Dokumen 05/Bioma-CO/2013.

Kusumaningrum, 2015, Analisis Kelayakan Finansial dan Ekonomi Pada Hutan Tanaman Industri PT 
Silva Nusantara Investama, UGMYogyakarta.

Klemperer, D.W. 2003. Forest resource economics and finance. McGrawHill. Inc. United States of America.

Maryunani \& Sutikno. 2006. Ekonomi Sumberdaya Alam. Malang: Badan Penerbit Fakultas Ekonomi Universitas Brawijaya

Muluk, Abdul. 2014. Simulasi Kayu Bulat Dan Investasi Shore leprosula di PT. Kutai Timber Indonesia. Tesis. Magister Ilmu Kehutanan. Fakultas Kehutanan. Universitas Mulawarman, Samarinda.

Nurjaya, I Nyoman, 2008. Moratorium Logging Dalam Perspektif Antropologi Hukum. Indonesia Dokumen

Rivai, Veithzal., Arviyan Arifin. 2010.Islamic Bangking System Bank Islam Bukan Hanya Solusi Menghadap Krisis, Namuan Solusi Dalam Menghadapi Persoalan Perbankan Dan Ekonomi Global. Bumi Aksara, Jakarta.

Rosalina, Mada, 2016. Analisis profit sharing pengusahaan Sengon berbasis ekonomi konvensional. Skripsi. Fakultas Kehutanan Universitas Mulawarman, Samarinda.
Prodan, M. 1968. Forest Biometrics. Pergamon Press. Oxford. London.

Soares, M 2018. Analisis Produksi Kayu Bulat dan Peluang Usaha Bagi Hasil Jenis Shorea Leprosula Dan Shorea Smithiana Di PT Inhutani I Bukit Bangkirai Balikpapan. Jurnal AGRIFOR Volume XVIII Nomor 1, Maret 2019.

Suhendang, E. 1997. Estimating Standing Tree Volume of Some Commercial Trees of the Tropical Rain Forest in Indonesia. In : Modern Methods of Estimating Tree and Log Volume (Edited by Wood and Wiant). West Virginia University Publications Services. Morgantown. USA.

Wood, G.B. and H.V. WIANT, Jr. 1990. Estimating the Volume of Australian Hardwoods Using Centroid Sampling. Aust. For. 53 : 271-274.

Wood, G.B., H.V. Wiant, Jr., R.J. Loy And J.A. Miles. 1990. Centroid Sampling : A Variant of Importance Sampling for Estimation the Volume of Sample Trees of Radiata Pine. For. Ecol. Manage., 36 : 233-243. Elsevier Sci. Pub. BV. Amsterdam. 